DOI: $10.15276 / E J .01 .2020 .1$

DOI: $10.5281 /$ zenodo.3974843

UDC: $35.07(477)$

JEL: H23, H24, H71, H72

\title{
FINANCIAL RESOURCES OF THE ADMINISTRATIVE SERVICE CENTER: STRUCTURE, FORMATION AND USE
}

\section{ФІНАНСОВІ РЕСУРСИ ЦЕНТРУ НАДАННЯ АДМІНІСТРАТИВНИХ ПОСЛУГ: СТРУКТУРА, ФОРМУВАННЯ І ВИКОРИСТАННЯ}

\author{
Hanna O. Hratsiotova, Senior lecturer of the department \\ Odessa National Polytechnic University, Odessa, Ukraine \\ ORCID: 0000-0002-8594-489X \\ Email: savhenko965@gmail.com \\ Victoria K. Safronova \\ Odessa National Polytechnic University, Odessa, Ukraine \\ Email:Vikaaa040s@gmail.com \\ Serhii V. Sizonenko \\ Odessa National Polytechnic University, Odessa, Ukraine \\ ORCID: 0000-0003-0128-9072 \\ Email:y.mordan@uabs.sumdu.edu.ua
}

Recieved 15.01.2020

Граціотова Г.О., Сафронова В.К., Сизоненко С.В. Фінансові ресурси центру надання адміністративних послуг: структура, формування і використання. Оглядова стаття.

В даній статті розглядаються такі проблеми як структура роботи центрів надання адміністративних послуг в Україні, описується фінансове забезпечення та фінансові ресурси центрів надання адміністративних послуг, виявлення проблем роботи Подільского центру надання адміністративних послуг, виокремлюються фактори, які сприяють підвищення якості надання адміністративних послуг у місті Подільск. Надання адміністративних послуг становить невід'ємну частину суспільства без винятку всіх країн. Проаналізовано послуги, що надаються органами державної влади, органами місцевого самоврядування, підприємствами, установами, організаціями, які перебувають в їх управлінні, що становлять сферу публічних послуг. Важливою складовою державних і муніципальних послуг є адміністративні послуги.

Ключові слова: адміністративна послуга, фінанси, фінансове забезпечення, фінансові ресурси, центр надання адміністративних послуг.

Hratsiotova H.O., Safronova V.K., Syzonenko S.V. Financial resources of the administrative service center: structure, formation and use. Review article.

This article deals with such problems as the structure of Administration Service Centres in Ukraine, describes the financial support and financial resources of Administration Service Centres, identifies problems with Podilsk Administration Service Centre, identifies factors that contribute to improving the administrative services quality in Podilsk. The administrative services provision is a society's integral part without exception in all countries. The services provided by government bodies, local authorities, enterprises, institutions, organizations under their management, which constitute the public services sphere are analyzed. An important component of state and municipal services are administrative services.

Keywords: administrative service, finances, financial assurance, financial resources, Administation Service Centre.

he existing system of the Administration Service Centre in Ukraine does not meet the population's expectations and needs. The ASC funding is limited. Given this, there is a risk of improper compliance with the law, dissatisfied citizens, poor conditions for servicing the customers.

\section{The analysis of recent researches and publications}

The mentioned aspects of funding and its consequences are considered in the scientific works of many domestic and foreign scientists. I. Holosnichenko, I. Koliushko, D. Bakhrakh, O. Sushynskyi, R. Kaliuzhnyi paid their attention to the of regulatory support issue; public administration and procedural aspects - A. Selyvanov, A. Nesterov; staffing - O. Reshevets, S. Dembitska; V. Tymoshchuk, O. Kulmenko, M. Keune, M. Krajewski, U. Neergaard devoted their studies to the investigation and consideration of foreign experience.

\section{Unsolved aspects of the problem}

Despite the availability of a significant amount of researches in these notions, theoretical and applied issues of funding for the administration service centre still remain open.

The aim of the article is to study the work structure of $\mathrm{t}$ Administration Service Centres and to find out how the financing of $t$ he Administration Service Centres takes place, especially on the example of Podilsk. 


\section{The main part}

An administrative service is the result of the power exercise by the administrative services subject at the request of a physical or a legal person, aimed at acquiring, changing or terminating the rights or obligations of such a person.

Administrative services in the current administrative reform are regarded as an important tool for public administration. Improving the process of administrative services provision is a key condition for reforming public authorities by implementing the idea of service states. By its nature, an administrative service is the issuance within the powers of governmental and local authorities at the request of individuals or legal entities permits, licenses, certificates, vouchers, as well as registration of acts, documents, rights, objects, issuance of other individual legal acts in order to ensure the legal registration of the conditions for the realization of their rights, freedoms and legitimate interests. Functions for the issuance of various permits and other documents have been developed as a state regulatory influence on economic processes simultaneously with the market relations formation [1].

The Administration Service Centres in accordance with the Law of Ukraine "On Administrative Services" began their work on 1 January, 2014. The establishment of such centres was aimed at facilitating the process of obtaining administrative services by citizens, in particular, by applying to only one institution - ASC [2].

The advantage is that a citizen applies for any administrative service to an administrator who works in an ASC. And the result of an administrative service is also received from the administrator of the ASC or by mail. Thus, corruption risks are reduced by eliminating the personal contact of the subject with the authority representative responsible for providing the service. According to the current legislation on the establishment of ASCs in Ukraine, single permit centres (SPCs) have started operating, in which business entities (legal entities and individuals - entrepreneurs) received permits, registration documents, submitted declarations, etc. In a particular way, the SPCs became the prototype of the ASCs, but served only businesses. A positive practice was taken into account even after the entry into force of the Law of Ukraine "On Administrative Services". The SPCs were to become an integral part of the ASCs.

According to the official website of the Ministry for Develepment of Economy, Trade and Agriculture of Ukraine the total number of the Administration Service Centres by region as of 01.01.2020 is 434 centres and 7 departments (Table 1) [3].

Table 1. The Information on the Total Number of the Administration Service Centres, by region as of 01.01.2020

\begin{tabular}{|c|c|c|c|}
\hline \multirow{2}{*}{$\begin{array}{c}\text { Administrative and } \\
\text { territorial unit }\end{array}$} & \multicolumn{3}{|c|}{ The number of the Admistration Service Centres } \\
\hline & LPA & LAs & General \\
\hline 1 & 2 & 3 & 4 \\
\hline Vinnytsia region & $\begin{array}{l}21 \text { and } 3 \text { territorial } \\
\text { subdivisions }\end{array}$ & $\begin{array}{c}17 \text { and } 3 \text { territorial subdivisions, } \\
7 \text { workplace offices }\end{array}$ & $\begin{array}{c}38 \text { and } 6 \text { territorial } \\
\text { subdivisions, } 7 \text { workplace } \\
\text { offices } \\
\end{array}$ \\
\hline Volyn region & 15 & 17 & 32 \\
\hline $\begin{array}{l}\text { Dnipropetrovsk } \\
\text { region }\end{array}$ & 22 & $\begin{array}{c}32 \text { and } 10 \text { territorial } \\
\text { subdivisions, } 16 \text { workplace } \\
\text { offices, } 3 \text { mobile }\end{array}$ & $\begin{array}{c}54 \text { and } 10 \text { territorial } \\
\text { subdivisions, } 16 \text { workplace } \\
\text { offices, } 3 \text { mobile }\end{array}$ \\
\hline Donetsk region* & $12(5 * *)$ & $\begin{array}{l}19 \text { and } 3 \text { workplace offices } \\
\left(13^{* *)}\right)\end{array}$ & $\begin{array}{l}31 \text { and } 3 \text { workplace offices } \\
\left(18^{* *}\right)\end{array}$ \\
\hline Zhytomyr region & 21 & 16 & 37 \\
\hline $\begin{array}{l}\text { Transcarpathian } \\
\text { region }\end{array}$ & 13 & 9 & 22 \\
\hline Zaporozhye region & 16 & 21 and 5 territorial subdivisions & $\begin{array}{c}37 \text { and } 5 \text { territorial } \\
\text { subdivisions, } 1 \text { mobile }\end{array}$ \\
\hline $\begin{array}{l}\text { Ivano-Frankivsk } \\
\text { region }\end{array}$ & 14 & 13 and 3 territorial subdivisions & $\begin{array}{c}27 \text { and } 3 \text { territorial } \\
\text { subdivisions }\end{array}$ \\
\hline Kyiv region & 24 & 22 and 8 workplace offices & 46 and 8 workplace offices \\
\hline Kirovograd region & 21 & 5 & 26 \\
\hline Luhansk region* & $10(4 *)$ & $\begin{array}{c}10\left(11^{*}\right) \text { and } 15 \text { workplace } \\
\text { offices }\end{array}$ & $\begin{array}{c}20 \text { and } 15 \text { workplace offices, } 2 \\
\text { mobile }\end{array}$ \\
\hline Lviv region & 20 & 18 and 7 territorial subdivisions & $\begin{array}{l}38 \text { and } 7 \text { territorial } \\
\text { subdivisions }\end{array}$ \\
\hline Mykolaiv region & 19 & 7 & 26 \\
\hline Odessa region & 24 & 14 and 3 territorial subdivisions & $\begin{array}{l}38 \text { and } 3 \text { territorial } \\
\text { subdivisions }\end{array}$ \\
\hline Poltava region & 24 & 17 and14 workplace offices & 41 and 14 workplace offices \\
\hline Rivne region & 15 & 10 & 25 \\
\hline Sumy region & 16 & $\begin{array}{l}15 \text { and } 2 \text { territorial subdivisions } \\
\text { and } 2 \text { workplace offices }\end{array}$ & $\begin{array}{c}31 \text { and } 2 \text { territorial } \\
\text { subdivision and } 2 \text { workplace } \\
\text { offices } \\
\end{array}$ \\
\hline
\end{tabular}


Continuation of the table 1

\begin{tabular}{|l|c|c|c|}
\hline \multicolumn{1}{|c|}{1} & 2 & 3 & 4 \\
\hline Ternopil region & 17 & 13 and 16 workplace offices & $\begin{array}{c}30 \text { and } 16 \text { territorial } \\
\text { subdivisions }\end{array}$ \\
\hline Kharkiv region & 27 & $\begin{array}{c}13 \text { and } 10 \text { territorial } \\
\text { subdivisions }\end{array}$ & $\begin{array}{c}40 \text { and } 10 \text { territorial } \\
\text { subdivisions }\end{array}$ \\
\hline Kherson region & 18 & 11 and 16 workplace offices & 30 and 16 workplace offices \\
\hline Khmelnytsky region & 17 & $\begin{array}{c}19,1 \text { territorial subdivisions, 11 } \\
\text { workplace offices and 2 mobile }\end{array}$ & $\begin{array}{c}36,1 \text { territorial subdivisions, } \\
\text { workplace offices, 2 mobile }\end{array}$ \\
\hline Cherkasy region & 20 & 14 and 6 workplace offices & 34 and 6 workplace offices \\
\hline Chernivtsi region & 8 & 14 and 2 workplace offices & 22 and 2 workplace offices \\
\hline Chernihiv region & 14 & 16 and 44 workplace offices & 30 and 44 workplace offices \\
\hline Kyiv & 10 and 4 subdivisions & 1 & $\begin{array}{c}11 \text { and 3 territorial } \\
\text { subdivisions }\end{array}$ \\
\hline Total: & 434 and 7 divisions & $\begin{array}{c}363 \text { and 44 territorial } \\
\text { subdivisions, 161 workplace } \\
\text { offices and } 8 \text { mobile ASCs }\end{array}$ & $\begin{array}{c}791 \text { and 51 territorial } \\
\text { subdivisions, 161 workplace } \\
\text { offices and } 8 \text { mobile ASCs }\end{array}$ \\
\hline
\end{tabular}

Source: Complied by authors on materials [3]

The structure of the centre includes an organizational combination in one office room for administrative bodies and their officials, which should ensure compliance with and functioning the organizational unity principle in the organization of the established list of administrative services.

Reception. In big cities, it is necessary to introduce advisors' positions on the ASCs functioning, i.e. jobs of employees who will provide advice on general issues of the ASCs schedule, the order of admission, and so on. It is advisable to place such an information department (reception) at the entrance to the ASCs premises in front of the sub-entities (part of the office), which receives documents from customers. Therefore, the reception staff (1-2 people) should provide general information to the newcomers to the institution, while their professional advice will be provided by the staff receiving the documents. In the case of small sizes of an ASC (for example, in towns or territorial points of the ASC), employees who carry out professional reception can provide all consulting and information services at the same time. That is, the creation of a separate reception is impractical. The sub-entity (workplaces) of receiving documents from consumers. This sub-entity provides customer service directly by receiving from them the documents necessary to resolve the case (Fig. 1).

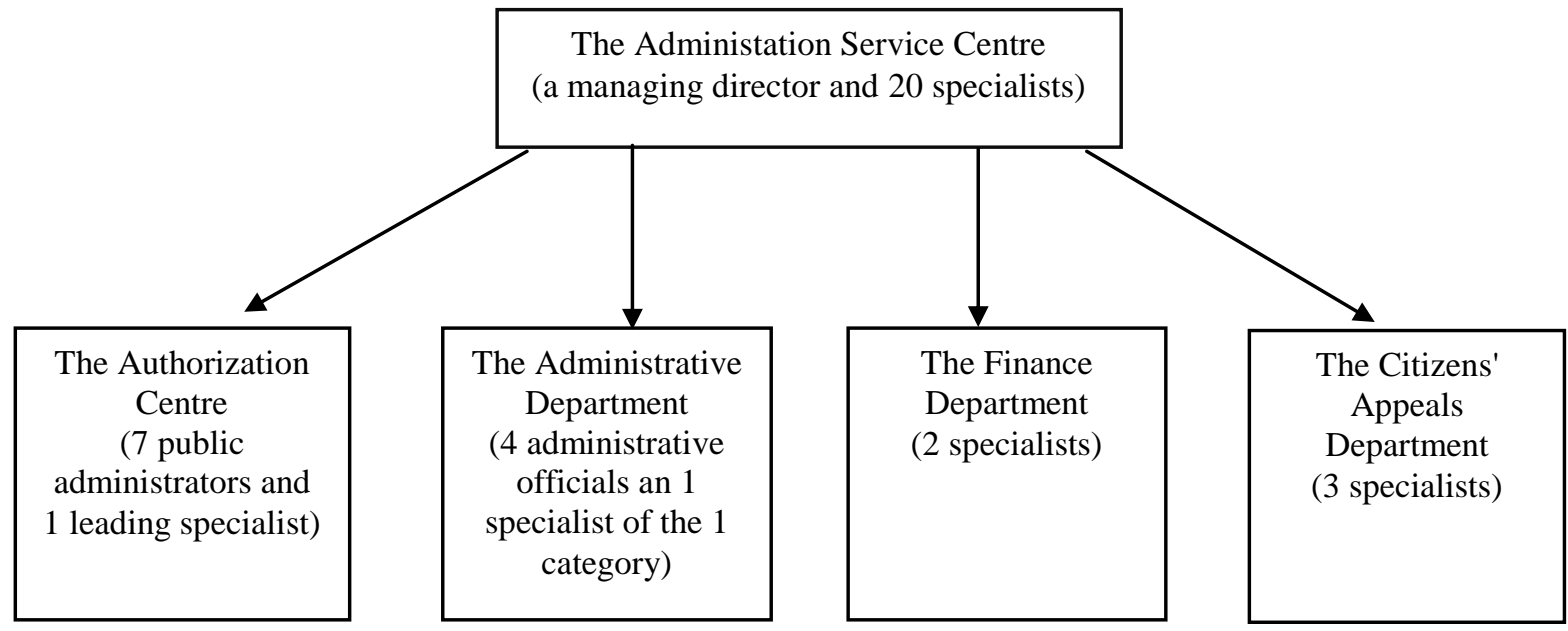

Fig. 1. The ASC Organizational Structure, Podilsk

Source: Complied by authors on materials [3]

The financial resources of an organization are the funds that are available to organizations and are intended for the certain financial obligations fulfillment.

Financial support is a variety of financial resources funds that are created and used to produce and sell products, works, services in various industries, as well as to finance other activities of organizations.

Financing and material support of the ASCs is carried out at the expense of the state budget and the local budget.

In 2012 the Law of Ukraine "On Administrative Services" was adopted, which regulates that executive authorities and other state bodies purchase forms for results registration of providing administrative services (except for their own forms of these bodies) from state-owned enterprises within the central government. executive body that implements state policy in the field of organization and control over the production of forms 
of securities, documents of strict reporting. Procurement of goods, works and services for the administrative services provision is carried out in accordance with the Law of Ukraine "On Public Procurement" [2].

Maintenance or any other support on a paid basis of the object of intellectual property rights used for the administrative services provision is carried out at prices set in accordance with Article 191 of the Commercial Code of Ukraine.

The norms of the law "On Administrative Services" give the right to bodies of city councils and district state administrations to include these expenses in their budget requests. Usually the sources of resources for the ASC creation are the State Budget (State Fund for Regional Development - SFRD), local budgets; grants, targeted assistance from international foundations and foreign organizations, individuals' charitable contributions; funds of business entities with which the executive committee has signed an agreement on the provision of related service.

In 2017, at the expense of SFRD, subventions from the State Budget to local budgets for the formation of united territorial communities infrastructure, the regional budget through international technical assistance and other extrabudgetary sources, projects to upgrade 24 ASCs of the region.

The opening of the renewed ASC in Podilsk was carried out at the expense of the SFRD (50.3\%), the local budget $(7.2 \%)$ (Table 2) [4, 5].

In our opinion, unfortunately, this funding is not enough because, based expert estimates, the current state of administrative services is characterized by many shortcomings, including: long queues; lack of clear explanations about the required documents and the need to visit institutions several times; availability of unreasonable types of administrative services; an administrative body's responsibilities transfer for the collection of certificates, visas, approvals, etc. to individuals; nreasonably high fees for certain types of services; limited days and hours for citizens' reception; the problem of access to necessary information for obtaining administrative services; unreasonably long deadlines for certain services provision; contradictory legal regulation and improper regulation of procedural issues $[4,5]$.

Burning issues of the ASCs' also remain:

- the premises improper arrangement in the number of ASCs (small area of the premises, location in the inconvenient part of the city for residents, lack of ramps for disabled people);

— insufficient number of the ASCs in Podilsk to ensure proper availability of administrative services;

- improper quality of technological cards in the number of ASCs;

- impossibility of receiving related services (lamination, photocopying, documents production, photography, saling the stationery) in the premises of the ASC in Podilsk;

- low level of introducing the electronic services in the ASC;

- lack of a machine for archival weaving of documents, which would reduce specialists' additional work;

— lack of monitoring and specialists' evaluation;

- low level of specialists' funding.

Table 2. The Structure of Financing Sources of the ASCs' Creation and Activities in 2018-2019 (Million UAH / \%) as of 31.01.2020

\begin{tabular}{|c|c|c|c|c|c|}
\hline \multirow{3}{*}{ Location } & \multicolumn{5}{|c|}{ The financing } \\
\hline & \multirow{2}{*}{ Total } & \multicolumn{4}{|c|}{ Inter alia } \\
\hline & & SRFD & Local budgets & EU & USAID \\
\hline Podilsk & $25 / 100$ & 5.3 & $\begin{array}{c}\text { 5/30 - city development fund; } \\
2 / 5.2 \text { - regional budget; } \\
0.2 / 1.5 \text { - city budget }\end{array}$ & - & $4.5 / 20.6$ \\
\hline Balta & $5.4 / 100$ & $3.1 / 30.4$ & $3.1 / 20$ & $0.2 / 10.3$ & - \\
\hline Artsiz & $6.3 / 100$ & $4.8 / 65$ & $0.5 / 11.6$ & - & - \\
\hline Ishmael & $8.8 / 100$ & - & 7.3/97 (regional) $1 / 3$ (city budget) & $0.4 / 13.5$ & $5.1 / 7.4$ \\
\hline Chernomorsk & $4.8 / 100$ & $4.2 / 95$ & $1.2 / 10$ (city budget) & $1.6 / 15.6$ & - \\
\hline Pivdenne & $5.6 / 100$ & $2.7 / 90$ & 2.4/10 (city budget) & $1.3 / 9.8$ & $3.2 / 5.5$ \\
\hline
\end{tabular}

Source: Complied by authors on materials [4, 5]

It should be noted that it would be expedient to provide training for the ASC administrators in territorial subdivisions of the Ministry of Justice of Ukraine, the State Migration Service of Ukraine, the State Service of Ukraine for Geodesy, Cartography and Cadastre, in order to improve their skills to provide administrative services and update the information and technology cards of administrative services provided by the ASC. The quality of administrative services can be changed through visitors' regular surveys.

In our opinion, in order to solve the presented problems, we need to create the necessary working conditions for the ASC staff, as well as convenient conditions for the population to visit the Administration Service Centre 
and get their results. Thus, overcoming the abovementioned problems will contribute to the proper functioning of Podilsk Administration Services Centre, which cannot be provided without the financial resources involvement [6-8].

\title{
Conclusions
}

Due to a detailed analysis of regulations and activities of the Administration Service Centre employees, it can be noted that this mechanism needs attention for further improvement. To date, both ASC employees and ASC consumers are not satisfied with the quality. There are also the following problems: low level of electronic service implementation; limited schedule of "reception hours" in various bodies; lack of a machine for archival weaving of documents, which would reduce the specialists' additional work; insufficient equipment of reception rooms. The cause of these problems is insufficient funding.

In our opinion, in order to improve the funding of the Administration Service Centre in Podilsk, it is necessary to join the U-LEAD with Europe programme, which will be able to modernize the Administration Service Centre. This programme includes the following areas of support:

— institutional support of the ASC: institutional functioning establishment of the ASC, staff training, informing and involving residents;

- material support: provision of furniture, office equipment, software, development of a new design / zoning of the ASC;

- special types of assistance, including setting up an electronic queue management system and a mobile ASC $[9,10]$.

\begin{abstract}
This article addresses such problems as the structure of the Administration Service Centres in Ukraine, describes the financial support and financial resources of the Administration Service Centres, identifies problems of the Administration Service Centres, identifies factors that contribute to improving the administrative services quality in Podilsk. Administrative services provision is an integral part of society without exception in all countries.

Services provided by public and local authorities, enterprises, institutions, organizations under their management constitute the sphere of public services. Depending on the entity providing the public service, there is a distinction between state and municipal services.

Thanks to a detailed analysis of the regulatory legal acts and the employees' activities of the Administration Service Centre, it can be noted that this mechanism requires attention for further improvement. To date, both ASC employees and ASC consumers are not satisfied with the quality. There are also the following problems: low level of electronic service implementation; limited schedule of "reception hours" in various bodies; lack of a machine for archival weaving of documents, which would reduce the specialists' additional work; insufficient equipment of reception rooms. The cause of these problems is insufficient funding.
\end{abstract}

\section{Список літератури:}

1. Адміністративні послуги: [посібник] /[Бригілевич I.І., Ванько C.I., Загайний В.А. та інші]; за заг. ред. Тимощука В.П. - Вид. 2 - ге, доповн. І доопрац. - Київ: СПД Москаленко О.М., 2011. $423 \mathrm{c}$.

2. Про адміністративні послуги: Закон України № 5203-VI. 06.09.2012. URL: http://zakon5.rada.gov.ua/ laws/show/5203-17.

3. Сайт міністрества розвитку економіки, торгівлі та сільського господарства України [Електронний ресурс]. - Режим доступу: https://www.me.gov.ua/?lang=uk-UA.

4. Оцінки населенням України якості надання адміністративних послуг (2019 рік, а також порівняння 3 минулими роками). Вересень 2019 р. Фонд «Демократичні ініціативи» [Електронний ресурс]. - Режим доступу: https://dif.org.ua/article/otsinki-diyalnosti-tsentrivnadannya-poslug-u-30-mistakh-ukraini.

5. Про інвестиційну діяльність: Закон України № 1560-XII. 18.09.1991// Відомості Верховної Ради України. 1999. № 47. Ст. 646.

6. Реєстр адміністративних послуг центральних органів виконавчої влади // Міністерство економічного розвитку і торгівлі України [Електронний ресурс]. - Режим доступу: http://www.me.gov.ua/Documents/List?lang=uk-UA\&tag=ReiestrAdministrativnikhPoslug.

7. Адміністративні послуги: Посібник / [В. Тимощук]; Швейцарсько-український проект «Підтримка децентралізації в Україні - DESPRO». - К.: ТОВ «Софія-А». - 2012. - 104 с.

8. Бандурака О.М., Коробов Н. Л., Орлов П. І., Петрова К. Л. Фінансова діяльність підприємств: Підручник. - К.: Либідь, 2002. - 384 с.

9. Кропивний С.Ф., Колот В.М. Підприємництво: стратегія, організація, ефективність. Навч. посібник. - К.: КНЕУ, 1998. 
10. Міністерство фінансів України [Електронний ресурс]. - Режим доступу: http://www. minfin.gov.ua.

11. Davydova, I., Balan, O., Danyliuk, O., Horbashevska, M., Bakulina, N., Samarchenko, I. (2019). Improvement of algorithms and procedures of decision support in the field of personnel management International Journal of Recent Technology and Engineering, 8 (4), pp. 2128-2132.

\section{References:}

1. Brygilevich, I.I., Vanko, S.I. \& Zagayniy, V.A. (2011). Administratyvni posluhy [Administrative services]. V.P. Timoshchuk (Ed.). (2d ed.). Kyiv: SPD Moskalenko O.M. [in Ukrainian].

2. Pro administratyvni posluhy: Zakon Ukrayiny № 5203-VI. 06.09.2012. [On Administrative Services: Law of Ukraine of September 6, 2012 No. 5203-VI]. [in Ukrainian].

3. Sayt ministerstva rozvytku ekonomiky, torhivli ta silskoho hospodarstva Ukrayiny [Website of the Ministry of Economic Development, Trade and Agriculture of Ukraine] https://www.me.gov.ua. Retrieved from https://www.me.gov.ua/?lang=en-UA [in Ukrainian].

4. Democratic Initiatives Foundation. (2019). Otsinky naselennyam Ukrayiny yakosti nadannya administratyvnykh posluh (2019 rik, a takozh porivnyannya z mynulymy rokamy) [Assessment of the quality of administrative services provided by the Ukrainian population (2019, as well as comparison with previous years)]. https://dif.org.ua. Retrieved from https://dif.org.ua/article/otsinki-diyalnostitsentriv-nadannya-poslug-u-30-mistakh-ukraini [in Ukrainian].

5. Pro investytsiynu diyalnist: Zakon Ukrayiny № 1560-XII. 18.09.1991[On investment activity: Law of Ukraine of September 18, 1991 No. 1560-XII.] (1999). Vidomosti Verkhovnoyi Rady Ukrayiny \& Announcements of the Verkhovna Rada of Ukraine, 47 [in Ukrainian].

6. Reyestr administratyvnykh posluh tsentral'nykh orhaniv vykonavchoyi vlady [Register of Administrative Services of Central Executive Bodies] (n.d.). Ministerstvo ekonomichnoho rozvytku i torhivli Ukrayiny \& Ministry of Economic Development and Trade of Ukraine. Retrieved from http://www.me.gov.ua/Documents/List?lang=uk-UA\&tag=ReiestrAdministrativnikServices [in Ukrainian].

7. V. Timoshuk, Swiss-Ukrainian project "Support for decentralization in Ukraine \& DESPRO". (2012). Administratyvni posluhy [Administrative services]. K.: Sofia-A LLC [in Ukrainian].

8. Banduraka, O.M., Korobov, N.L., Orlov, P.I. \& Petrova, K.L. (2002). Finansova diyalnist pidpryyemstv [Financial activity of enterprises]. K.: Libid [in Ukrainian].

9. Kropivny, S.F. \& Kolot, V.M. (1998). Pidpryyemnytstvo: stratehiya, orhanizatsiya, efektyvnist [Entrepreneurship: strategy, organization, efficiency]. K.: KNEU [in Ukrainian].

10. Ministerstvo finansiv Ukrayiny [Ministry of Finance of Ukraine] http://www.minfin.gov.ua. Retrieved from http://www.minfin.gov.ua [in Ukrainian].

11. Davydova, I., Balan, O., Danyliuk, O., Horbashevska, M., Bakulina, N., Samarchenko, I. (2019). Improvement of algorithms and procedures of decision support in the field of personnel management International Journal of Recent Technology and Engineering, 8 (4), pp. 2128-2132.

\section{Посилання на статтю:}

Hratsiotova H.O. Financial resources of the administrative service center: structure, formation and use / H.O. Hratsiotova, V.K. Safronova, S.V. Syzonenko // Економічний журнал Одеського політехнічного університету. - 2020. - № 1 (11). - C. 5-10. - Режим доступу до журн.: https://economics.opu.ua/ejopu/2020/No1/5.pdf. DOI: 10.15276/EJ.01.2020.1. DOI: 10.5281/zenodo.3974843

\section{Reference a JournalArticle:}

Hratsiotova H.O. Financial resources of the administrative service center: structure, formation and use / H.O. Hratsiotova, V.K. Safronova, S.V. Syzonenko // Economic journal Odessa polytechnic university. - 2020. - № 1 (11). - C. 5-10. - Retrieved from https://economics.opu.ua/ejopu/2020/No1/5.pdf.

DOI: 10.15276/EJ.01.2020.1. DOI: 10.5281/zenodo.3974843 